\title{
PReS-FINAL-2092: Bone marrow cells (BMC) added to platelet-rich plasma (PRP) for treatment of bone degenerative processes in JIA patients: follow-up of 2 cases
}

\author{
P Salvati ${ }^{*}$, S Callegari ${ }^{2}$, G Tripodi ${ }^{3}$, MB Michelis ${ }^{4}$, S Boero ${ }^{4}$, R Lorini $^{1}$, MG Alpigiani ${ }^{1}$ \\ From 20th Pediatric Rheumatology European Society (PReS) Congress \\ Ljubljana, Slovenia. 25-29 September 2013
}

\section{Introduction}

In Regenerative Medicine one or more regenerative factors can be applied inside a cartilagine or bone defect to obtain a more rapid and complete healing. Bone Marrow Cells (BMC) added to Platelet-Rich Plasma (PRP) contain stromal cells which can differentiate in osteoclasts and osteoblasts and can be able to form osteogenic tissue and to repair bone defects secondary to degenerative processes.

\section{Objectives}

We report 2 cases in which we implanted BMC plus PRP in the osteonecrotic region with a clinical and imaging follow-up.

\section{Methods}

The first case is a 17-year old boy, followed at our Department, affected by JIA since he was 2 years old. He presented a systemic form, evolved into a polyarticular form, treated with steroids and immunosuppressor drugs. The patient had a good response to treatment with Enbrel, which he is still taking. In January 2009, he presented right hip pain and functional limitation. In July 2009 he underwent MRI of the hip joints which showed osteonecrosis in chondral/subchondral regions at the superior-external convexity of the right femoral head. We recommended deambulation with crutches and no weight bearing. Because of the persistence of joint symptoms, in July 2010 we implanted BMC plus PRP in the osteonecrotic region with improvement of pain and mobilization. In October 2010, he presented left hip pain.

${ }^{1}$ Pediatrics, Istituto G. Gaslini, Genova, Italy

Full list of author information is available at the end of the article
MRI showed focal osteonecrosis in subchodral region of left femoral head convexity. For this reason, we made a second BMC plus PRP implantation in the left hip. The MRI, made on January 2012, showed any changes concerning the morphology of femoral heads and subchondral erosions. The last MRI, made on December 2012 showed no changing of lesions and a mild improvement of right hip. Our patient autonomous walks, without joint pain and with improved hip movements, since January 2011; he keeps on Enbrel and nsaids. The second case is a 20 -year and 4 month old girl with extended oligoarticular JIA diagnosed when she was 2 years old. On July 2012 after an injury, a flare occurred in the left knee. MRI, made on October 2012 showed intra-articular effusion with diffuse synovial thickening, small bone subchondral erosions of medial femoral condyle. She underwent a surgical procedure where we implantated BMC plus PRP on January 2013 which resulted in improvements of mobility and reduction of pain.

\section{Results}

All two patients had an improvement of their mobility and pain reduction with no progression of articular damages on MRI imaging.

\section{Conclusion}

To the best of our knowledge, there are no literature data on the use of BMC plus PRP in pediatric patients affected by JIA. Considering the obvious limitations of our case reports, we observed a good short-term outcome. Therefore, follow-up is essential to check if BMC plus PRP implantation represents only a palliative care to delay 
surgical treatment or if it is a valid alternative to traditional orthopedic surgery.

\section{Disclosure of interest}

None declared.

\section{Authors' details}

${ }^{1}$ Pediatrics, Istituto G. Gaslini, Genova, Italy. ${ }^{2}$ Istituto G. Gaslini, Genova, Italy. ${ }^{3}$ Service of Immuno-Hematology and Transfusion Medicine, Instituto G.

Gaslini, Genova, Italy. ${ }^{4}$ Pediatric Surgery, Istituto G. Gaslini, Genova, Italy.

Published: 5 December 2013

\section{References}

1. Gothard D, et al: Lab Chip 2011, 11(7):1206-20.

2. Nauth A, et al: J Orthop Trauma 2010, 24(9):543-6.

3. Calori GM, et al: Injury 2009, 40(Suppl 3):S67-76.

doi:10.1186/1546-0096-11-S2-P104

Cite this article as: Salvati et al:: PReS-FINAL-2092: Bone marrow cells (BMC) added to platelet-rich plasma (PRP) for treatment of bone degenerative processes in JIA patients: follow-up of 2 cases. Pediatric

Rheumatology 2013 11(Suppl 2):P104.

Submit your next manuscript to BioMed Central and take full advantage of:

- Convenient online submission

- Thorough peer review

- No space constraints or color figure charges

- Immediate publication on acceptance

- Inclusion in PubMed, CAS, Scopus and Google Scholar

- Research which is freely available for redistribution

Submit your manuscript at www.biomedcentral.com/submit
C Biomed Central 